\title{
Humanism and Solidarity in Brazilian Foreign Policy Under Lula (2003-2010): Theory and Practice ${ }^{1}$
}

\author{
Carlos Aurélio Pimenta de Faria \\ Pontifical Catholic University of Minas Gerais (PUC-Minas), Brazil \\ Clarisse Goulart Paradis
}

Ph.D Candidate in Political Science, Federal University of Minas Gerais (UFMG), Brazil

\begin{abstract}
The "humanistic" or "solidarity-based" trend in the Brazilian strategy of international insertion, adopted after the rise to power of President Lula and considered innovative, consolidated the objective of prioritizing the South-South axis and can be explained by domestic, regional, and systemic reasons. This strategy was put into practice by increasing the international aid granted by Brazil, by transferring resources and technology and by the emphasis placed on conveying to partner countries some of the domestic social policies and programmes developed successfully by the Brazilian government. The aims of this paper are: (a) to look at how this "humanism" and "solidarity" appeared in the discourse of the Brazilian authorities; (b) to discuss the reasons for them and their logic in the national, regional, and systemic dimensions; and (c) to map the initiatives adopted, the preferred partners and areas, the resources used and the intragovernmental connections necessary for their implementation.
\end{abstract}

Keywords: Foreign policy; Brazil; humanistic; solidarity

$\left\{\mathrm{y}\right.$ the end of the first decade of the $20^{\text {th }}$ century, Brazil had attained unprece2012; Hurrell, 2008; Rouquié, 2008), a position long aspired by the Brazilian elite (Lima, 2005a). Evidence of this is so plentiful that examples are unnecessary. Such a shift was made possible by both international and domestic factors.

In such a context, much has been said and written about the foreign policy put into practice during the Lula administration (2003-2010): that it was "politically engaged" 
(engajada) (Almeida, 2004); that it sought a "sovereign presence" in the world system (Souto Maior, 2004); that it was based on a search for a new "diplomatic architecture" (Almeida, 2005); that it followed a strategy of attaining "autonomy through diversification" [of partners] (Vigevani and Cepaluni, 2007) and that it was based on a "charismatic diplomacy" that was "impossible to transfer" (Ricupero, 2010), among many other labels and adjectives. ${ }^{2}$ Celso Amorim, Minister of Foreign Affairs during Lula's two terms in office, said in an interview immediately after his appointment to lead Itamaraty once again ${ }^{3}$ that the country's foreign policy would be "lofty and active" (altiva e ativa). In another interview, towards the end of his eight years as Lula's foreign affairs minister, Amorim stated that he preferred to label it as "fearless and solidarity-based" (desassombrada $e$ solidária) (Amorim, 2010).

Until quite recently, few Brazilian foreign policy analysts had stressed the importance that this emphasis on "humanism" and "solidarity" had on Lula's strategy of international insertion, even if, as we will see, it was strongly present in public speeches given both by Lula and Amorim since the very beginning, and even if it was almost immediately translated into practice. Lima and Hirst (2006: 22), however, state that the "inclusion of the social agenda as a major topic of foreign affairs was one of the first and most important innovations".

This new tendency of the country's foreign policy, regarded as innovative, consolidated the objective of prioritizing the South-South axis. With this objective, Brazil established closer ties to countries on the periphery of capitalism, which can be explained by domestic, regional, and systemic reasons. This strategy was put into practice, inter alia, by the increase in international aid granted, the transfer of resources and technology, and the emphasis placed on conveying to partner countries some of the domestic social policies and programmes developed successfully by the Brazilian government.

This paper aims to analyse this aspect of the country's foreign policy in discourse and in the analytical and empirical dimensions. In other words, its objectives are: (1) to look at how this "humanism" and "solidarity" appeared in the discourse of the Brazilian authorities; (2) to discuss the reasons for them and their logic, in the national, regional, and systemic dimensions; and (3) to map the initiatives adopted, the preferred partners and areas, the resources used and the intragovernmental connections necessary for their implementation. The structure of the paper will follow these objectives and attempt to unveil both the theory and the practice of Brazilian self-proclaimed "humanistic" foreign policy during the period 2003-2010. 


\section{The Rhetoric of Solidarity and Humanism in Lula's Foreign Policy}

The activism of Brazilian foreign policy under Lula may be gauged by the intensity of the so-called presidential diplomacy during his time in office. Table 1 compares the official presidential trips to foreign countries made by Cardoso (1995-2002) and by Lula (2003-2010).

Table 1. Official Presidential Trips Abroad: Cardoso and Lula

\begin{tabular}{|c|c|c|c|c|}
\hline & \multicolumn{2}{|c|}{ Cardoso (1995-2002) } & \multicolumn{2}{|c|}{ Lula (2003-2010) } \\
\hline Total trips abroad & \multicolumn{2}{|c|}{94} & \multicolumn{2}{|c|}{146} \\
\hline Number of countries visited & \multicolumn{2}{|c|}{44} & \multicolumn{2}{|c|}{85} \\
\hline Number of visits & \multicolumn{2}{|c|}{135} & \multicolumn{2}{|c|}{254} \\
\hline \multicolumn{5}{|c|}{ Number of countries visited and number of visits by region } \\
\hline & Countries & Number of visits & Countries & Number of visits \\
\hline Africa & 3 & 5 & 21 & 32 \\
\hline Antarctica & 0 & 0 & 1 & 1 \\
\hline Asia & 8 & 8 & 10 & 19 \\
\hline Europe & 14 & 44 & 18 & 57 \\
\hline Central America \& Caribbean & 4 & 6 & 11 & 21 \\
\hline Middle East & 1 & 1 & 10 & 12 \\
\hline North America & 3 & 15 & 2 & 20 \\
\hline South America & 11 & 56 & 12 & 92 \\
\hline TOTAL & 44 & 135 & 85 & 254 \\
\hline
\end{tabular}

Source: Adapted from Ribas and Faria (2011).

Whereas Cardoso's presidential diplomacy had been widely praised in Brazil (Danese, 1999), the intensity of Lula's personal engagement in international affairs initially surprised many of his fellow citizens, largely due to prejudice, since the former industrial worker did not have a university degree and spoke only Portuguese. ${ }^{4}$ As a matter of fact, the comparison presented above not only illustrates the priority Lula gave to foreign affairs, but also shows that the South-South axis really became of particular concern during his administration.

Our objective in this section is not to present a quantitative analysis or analyse the circumstances in which Lula and Amorim made reference to their intention to develop foreign policy strategies based on solidarity and humanism, made clear in their innumerable public speeches, both abroad and at home. Neither do we intend to perform any kind of formal discourse analysis. Our goal here is much more modest: to select and present a 
few passages in order to show that such a strategy was conceived since the very beginning of the Lula administration, to illustrate that it was clearly and frequently presented and to highlight how powerful this rhetoric was at times. As we will see, the fact that the president could claim, as he did on several occasions, that he himself had experienced poverty, hunger, exclusion and migration motivated by economic reasons was not the only reason for which it was so powerful. ${ }^{5}$

In his inauguration speech on January 1,2003 , Lula made it clear that the link between domestic and foreign policies in his government would not just be "developmental". It must be borne in mind that in Brazil, foreign policy has traditionally been regarded as an instrument to promote economic development at home. Lima and Hirst (2006: 21) have also stressed this point: "the government's fight against poverty and unequal income distribution at home and its assertive and activist foreign policy can be viewed as two sides of the same coin".

In the aforementioned inaugural speech, Lula called upon the nation to make the "end of hunger a great national cause", a "crusade". He said, "Our foreign policy will also reflect the desires that were expressed in the streets. In my government, Brazilian diplomatic action will be oriented by a humanistic perspective and will be, above all, an instrument for national development". The main priority was to build "a continent that is politically stable, prosperous and united, on the basis of the ideals of democracy and social justice". The country would back the efforts to make the United Nations and its agencies efficient instruments for promoting "social and economic development, to fight poverty and inequality".

We are starting a new chapter in Brazilian History today, not as a submissive nation, (...) not as an unjust nation, passively watching the suffering of the poorest, but as a lofty (altiva) and noble nation that will affirm itself courageously in the world as a nation for all, free from class, ethnic, gender or belief distinctions. ${ }^{6}$

The message Lula took to Porto Alegre (III World Social Forum) and to Davos (World Economic Forum) later that same month (January 2003) was not any different: he recognized that his electoral victory meant hope not only for Brazilians, but also for leftist forces all over the world. Lula stated that it was no longer possible to carry on with an economic order that allowed children to starve. "The truth is that the social problems of the world had never been discussed in Davos", said Lula in Porto Alegre. Two days later, he said in Davos that "the construction of a new international economic order, one that is more just and democratic, is not only an act of generosity, but is also particularly an attitude of political intelligence". To justify his proposal to create an international fund to fight poverty and hunger in the third world, Lula stated that "it is necessary to admit 
that hunger and poverty are usually [part of] the cultural environment (caldo de cultura) where fanaticism and intolerance arise". The speech at Davos was thus concluded: "We urgently need to unite around a world pact for peace and against hunger. And rest assured that Brazil will do its part".

Lula regarded the task of convincing leaders, sensitizing audiences and setting the international agenda as part of his responsibility. This is clear when one looks at his agenda and reads his speeches. But Lula had more than a moral discourse, personal charm, charisma and his own life story to support his "crusade". He also insistently presented Brazilian social policies created or improved by his government, such as Fome Zero (Zero Hunger) and the conditional cash transfer programme called Bolsa Família, which became the world's greatest programme of that sort, as best practices to be emulated. In 2011, Lula's former minister, José Graziano da Silva, was elected Director-General of the UN Food and Agriculture Organization (FAO). Lula once said that "Brazil wants to be proud to be the first country to accomplish all the Millennium Goals established in Rome". ${ }^{7}$ In fact, Brazil managed to accomplish the first goal ("to eradicate extreme poverty and hunger") well before the deadline. But it was not only the domestic policies that were praised and sold as examples to other developing countries. The social programmes financed by the IBSA (India, Brazil and South Africa) Forum Fund in non-member countries, for example, received an award from the UN.

Both Lula and Amorim stressed the "humanistic" spirit that characterized Brazil's mobilization in the domestic and international spheres on many occasions. According to the rationale that was being disseminated, "the fight against exclusion and inequality is not a mere consequence of growth, but its mainspring" (mola mestra). As Lula had strongly condemned the invasion of Iraq, which took place on March 20, 2003, he said repeatedly that "our war is against hunger and poverty, and that is the only war that interests us". But perhaps the most striking argument used by him on countless occasions in his speeches around the world was that hunger can be considered the most lethal weapon of mass destruction, since it killed "twenty thousand people a day and eleven children per minute", affecting nearly one quarter of humanity. The goal of "transforming hunger into a political issue" became clear and was easily recognizable. "We will not be successful in the fight against hunger if we do not radically change the standards of international cooperation. It is necessary to turn the page on the models imposed from abroad". "With the IBSA Fund we are proving that it is not necessary to be rich in order to show solidarity, that it is possible to help without interfering in other nations' internal affairs". ${ }^{9}$

The rhetoric of solidarity was also frequently presented as part of a defence of Brazilian national interests, once defined by Amorim as the well-being of the Brazilian people. Brazilian diplomatic efforts to liberalize the international commerce of agricultural goods 
in multilateral institutions - particularly in the World Trade Organization (WTO), where the country led the articulation of the G20 in 2003 - were also linked to the search not only for a more equitable international system, but also for social justice. As Lula mentioned several times, "there will be no peace and security [in the world] without economic development and social justice". ${ }^{10}$ Targeting the heavy subsidies for agriculture practised by the USA and Europe, both Lula and Amorim emphasised many times that "it cannot be possible that cows in some developed countries earn more than two dollars a day in subsidies, while half of the world's population has to survive on less than that". ${ }^{11}$ In another speech, Lula said that "the sum of resources spent on subsidies for agriculture is equivalent to six times the yearly additional value necessary to make the achievement of the Millennium Goals possible. Such a situation must change". ${ }^{12}$ According to Amorim,

(...) for the first time in the history of trading diplomacy we have managed to put together [through the G20] two seemingly antagonistic objectives: trade liberalization and social justice. This has only been possible with this background which, in a way, President Lula created with his crusade against hunger. ${ }^{13}$

Lastly, but no less important, we must mention the relevance and opportuneness of a term/concept coined by Minister Amorim: "non-indifference". Whereas non-intervention and the defence of self-determination have been traditional hallmarks of Brazilian diplomacy, as several analysts have stressed, the new concept "non-indifference" was first used to justify the Brazilian leadership of MINUSTAH in Haiti, the UN mission established in 2004 under Chapter 7 of the UN Charter. The term was later used by Brazilian diplomatic authorities to try to legitimize not only humanitarian assistance, but also debt relief and technical cooperation with the official goal of promoting social development in other third world countries. Just as "the right to intervene" was largely used by the USA in their War against Terror after the Iraq War, "non-indifference" also legitimized a sort of intervention, but for the sake of social justice (Lima, 2005b). And in Haiti, Amorim believed that Brazil was "creating a new paradigm in international cooperation to solve conflicts. (...) What we desire is that our action in Haiti turns out to be a model, at this moment in which the UN is undergoing profound transformations". ${ }^{14}$

It is therefore possible to say that Lula worked hard in his "crusade" (or "apostolate", as Amorim once said) to set the international agenda and to disseminate Brazilian policies, becoming a kind of international policy entrepreneur. And a very successful one, according to many observers and analysts. ${ }^{15}$ But how can one explain such a "crusade"? What are the reasons behind the humanistic and solidarity-based foreign policy developed by Brazil during Lula's presidency? We will attempt to answer these questions in the next section. 


\section{Domestic, Regional and Systemic Reasons that guided Lula's Humanistic Foreign Policy}

Although the individual, psychological motivations for launching this innovation in Brazilian foreign policy could be employed in our search for an explanation, as we saw in the previous section, in the following discussion we will emphasise the domestic, regional, and systemic variables. ${ }^{16}$

It must be initially said that, although the Workers' Party's (PT) rule in Brazil and "Lulismo" have been viewed as "pragmatic" - at least in comparison to other Latin American left-wing governments that rose to power, in what has been labelled as a "pink wave" that swept the region in this century's first decade (Panizza, 2006) -, it is hard to distinguish the political/ideological reasons behind the emergence of that humanistic trend in Brazilian foreign policy from the more pragmatic ones. Be that as it may, we should always ask ourselves if there really are politics without ideology.

Lula won the presidential elections in 2002 after also having disputed the three previous ones. His victory was possible not only due to a nationwide mass mobilization led by his party and his charismatic personality. His appeals to social justice during the campaign were combined with a promise to preserve the orthodoxy of the country's economic policies in order to calm down the markets and to gain the confidence of the middle classes. The neoliberal policies of Lula's predecessor, Cardoso, of the Brazilian Social Democracy Party (PSDB), would not be undone at the cost of instability. Economic orthodoxy may have marked Lula's first term in office, but as well as departing from the privatizations that took place during the government of the Social Democrats, the administration also immediately started putting into practice the long aspired foreign and social policies preached by the PT.

According to official expectations, these two policies, which were "two sides of the same coin", would be the trailblazers of the country's project of social and economic transformation. If social and economic change would inevitably come about slowly, self-esteem could be quickly induced by the forcefulness of the social justice discourse and by a renewed appraisal of the country's role in a changing world. The fact that sustained national economic improvement ensued was due both to external good fortune (particularly the commodities boom) and the progressive expansion of the internal market, fuelled by the social policies, successive increases in the minimum wage, novel forms of access to credit and the creation of millions of new jobs. Upward social mobility, material improvement and a sense of collective pride in the country (Anderson, 2011; Burges, 2005) strengthened the leading role Brazil was playing on several international stages. These were to be compared, according to the new Brazilian foreign policymakers, to the increased social 
inequalities produced during the previous government and the diplomatic fidelity to the United States, with no visible domestic impact, which was the guideline of the Social Democrats.

Thus, the strategy of solidarity-based international insertion, stressing the SouthSouth axis, was domestically produced, legitimized and reinforced by the character of the Brazilian political leader, by political competition and by the need to produce economic improvements. The Brazilian economy was among the world's first to recover after the 2008 Wall Street Crash, which took place during Lula's second term. Such a performance was attributed, to a large extent, to both foreign and social policies, as domestic demand kept the machine working and Brazilian exports were no longer dependent mainly on developed countries (China became Brazil's main commercial partner in 2009).

Regional factors also played an important role, as the new Brazilian foreign policy sought to reinforce the traditional priority given to South America, treating it as a renewed priority. However, it quickly became evident that the kind of bold regional leadership initially preached by Lula and the PT would not work out. As if the huge regional asymmetries were not enough to make most of the Brazilian initiatives suspicious, Venezuelan president Hugo Chávez had also begun expanding his regional ambitions through the ALBA (Bolivarian Alternative for the Americas) and his petro-diplomacy (Burges, 2007).

Brazil's regional leadership had several interconnected purposes: to transform the open regionalism of the 1990s into a post-liberal one, which would supposedly promote common political, strategic and social objectives; to reduce or prevent US hegemony over the continent; to promote regional trade and the interests of Brazilian companies (and the Lula government strongly backed the internationalization of the country's companies); to support, both directly and indirectly, like-minded political leaders in neighbouring countries; and last but by no means least - on the contrary -, to make the region a platform for consolidating Brazil as a global player (Spektor, 2011). According to that rationale, the Brazilian leadership then had to be based on solidarity and humanism, which also demanded a willingness on Brazil's part to act as a regional integration paymaster. ${ }^{17}$

The global impact of the September 11, 2001 events is of central importance for understanding the opportunities provided by the international system for developing the Brazilian strategies. As the US-led War on Terror strongly promoted a securitization of the international agenda and made the US concentrate on a different region, Latin American countries found themselves free to pursue more autonomous objectives. The mostly ruinous legacy of the neoliberal policies of the 1980s and 1990s (or at least such a perception) certainly played an important role, as it made possible the upsurge of the "pink wave" mentioned earlier (Panizza, 2006; Vilas, 2005). The rhetoric of the Brazilian authorities stressing humanism and solidarity, as well as the policies promoted by the country in both 
the domestic and international spheres, helped to revive the North-South divide. The War on Terror was contrasted with the war against poverty, and the selfish objectives of trade liberalization and the hegemony of the few developed nations started to be forcefully denounced in the streets and by dozens of leaders of developing countries.

Traditional Brazilian ambitions of reforming the institutional structure of the international system, particularly the UN, where Brazil demands a seat in the Security Council, are also said by many to be an important motivation for the priority given to the SouthSouth axis. This is so because the new partners and beneficiaries of the cooperation Brazil is implementing could lead to greater political support and possibly new votes in its favour.

The 2008 outbreak of the profound financial crisis that still limits the international impetus and influence of the developed nations has been interpreted in the periphery as a sign and an opportunity. The transformation of BRIC (Brazil, Russia, India, China) from an acronym into a group of emerging countries that endeavour to coordinate their international positions, and the subsequent expansion to include South Africa, should be regarded as one of the many manifestations of this perception.

Having analysed the rhetoric of solidarity and humanism in Lula's foreign policy and very briefly presented the domestic, regional, and systemic reasons that drove such an innovation, our task in the next section is to discuss how it was translated into practice.

\section{Humanistic and Solidarity-based Brazilian Foreign Policy in Lula's Government: Priorities, Projects and Intragovernmental Coordination}

The "humanistic" and "solidarity-based" trend in Brazilian foreign policy was brought to life by a series of projects, activities and programmes implemented through a network of governmental and nongovernmental organizations. These projects and actions included: Brazil's methodological transfer of some of its main policies through the provision of South-South technical cooperation, debt relief for poorer countries and Brazil's commitment to help countries affected by natural disasters or conflict by means of international humanitarian assistance. The purpose of this section is to map these initiatives, the key partners, resources, and intragovernmental connections necessary for their implementation. ${ }^{18}$

The policies and projects in question are considered "humanistic" and "solidarity-based" because, as stated earlier, they were justified in the Lula government by the sharing of values and interests with other countries of the South; by the sense of duty or "moral obligation" to protect individuals from another country; by the guiding principle of asking no counterpart to these actions from recipient countries; and by the Brazilian 
government's involvement in actions that sought to alleviate people's poverty, hunger and misery. The next subsections will briefly touch on the priorities, policies, and programmes of the following three areas: (1) South-South technical cooperation; (2) humanitarian assistance; and (3) financial cooperation. We will then conclude by presenting the intragovernmental coordination efforts and structures necessary for implementing these policies and programmes.

Before examining the practice of international solidarity in Lula's foreign policy, however, another comparative exercise may be useful in order to make the administration's priorities even clearer. The great emphasis placed by the Lula government on the "social question" in its international agenda may also be attested by a content analysis of the bilateral "international acts" signed by Brazil during 2003-2010. Such research is greatly facilitated by the fact that the Itamaraty's Department of International Acts (Divisão de Atos Internacionais) has a database on its website that enables access to all the acts signed and a search for specific key words. In this regard, a comparison between the Cardoso (19952002) and Lula (2003-2010) governments is revealing. The aforementioned site has a register of 845 bilateral acts signed during Cardoso's years in office, a figure that more than doubled during the following government (1,896 bilateral acts signed). This difference proves the great international activism of the Lula administration. For the purposes of this article, however, it is more important to compare the results of the search for the keyword "social development" in the text of those agreements. This expression appears in 576 of the bilateral acts signed during the Cardoso administration (68.2\% of the total), whereas it appears in 1,546 of the 1,896 bilateral acts signed during Lula's government (81.6\%). ${ }^{19}$

\section{South-South Technical Cooperation during Lula's Government}

The South-South cooperation is not a new phenomenon, but it has been deeply reformulated and enhanced in the last decade or so. According to Silva (2010), the motivation for undertaking this cooperation is to share interests and mutual benefits. In this sense, the South-South cooperation had an important role during the Cold War, after the articulation of the Non-Aligned Movement at the Bandung Conference in 1955, and in the operation of the G77, created in 1964. The oil crisis, the international recession and the debt crisis in peripheral countries during the 1970s and 1980s caused a significant reduction in development cooperation, which affected both North-South and South-South cooperation. Only in the $21^{\text {st }}$ century have we been able to see the South-South cooperation enter a new phase. According to Silva, several factors contributed to this revival. The rise of some developing countries through economic growth and social improvements enabled them to exercise leadership roles in the periphery of capitalism and become providers of 
cooperation. The creation of the Millennium Goals in 2000 added urgency to the problems of the South. Finally, the crisis and the disappointment with the cooperation initiatives came from the North, which have frequently ended up with not very encouraging results for the recipient countries, making the asymmetries of power even more evident and strengthening the dependence of peripheral countries (Silva, 2010).

The South-South Technical Cooperation, also known as technical cooperation for development, or horizontal cooperation, is one of the cooperation modalities delivered by Brazil. ${ }^{20}$ It was "reinvigorated" from the beginning of the Lula government, as pointed out by Puente (2010). This was due to the expansion of relations and to an approximation with the countries of the periphery, as well as to the growing human and financial resources allocated to the Brazilian Agency for Cooperation (ABC). ${ }^{21}$

The following figure shows the evolution of the ABC's budget from 1995 to 2010. One can see that from 2004 to 2005 there was a significant budget increase, from nearly US\$ 8 million to US\$ 37 million (Puente, 2010: 294). One explanation for this sudden increase was the fact that Brazil has been carrying out cooperation projects in Haiti, where it leads the UN peacekeeping mission, MINUSTAH, which began in 2004. In the following years the budget fell in relation to 2005 and increased again in 2009. Nevertheless, from the last year of Cardoso's presidency (2002) ${ }^{22}$ and during the Lula administration, the amount of resources allocated to the $\mathrm{ABC}$ increased significantly. Notice, however, that a study conducted by the ECOSOC and the OECD showed that in 2008 Brazil was only the eighth donor among developing countries, responsible for just $2.6 \%$ of the resources mobilized (apud Souza, 2012: 90).

Figure 1. ABC Budget (1995 - 2010), in R\$

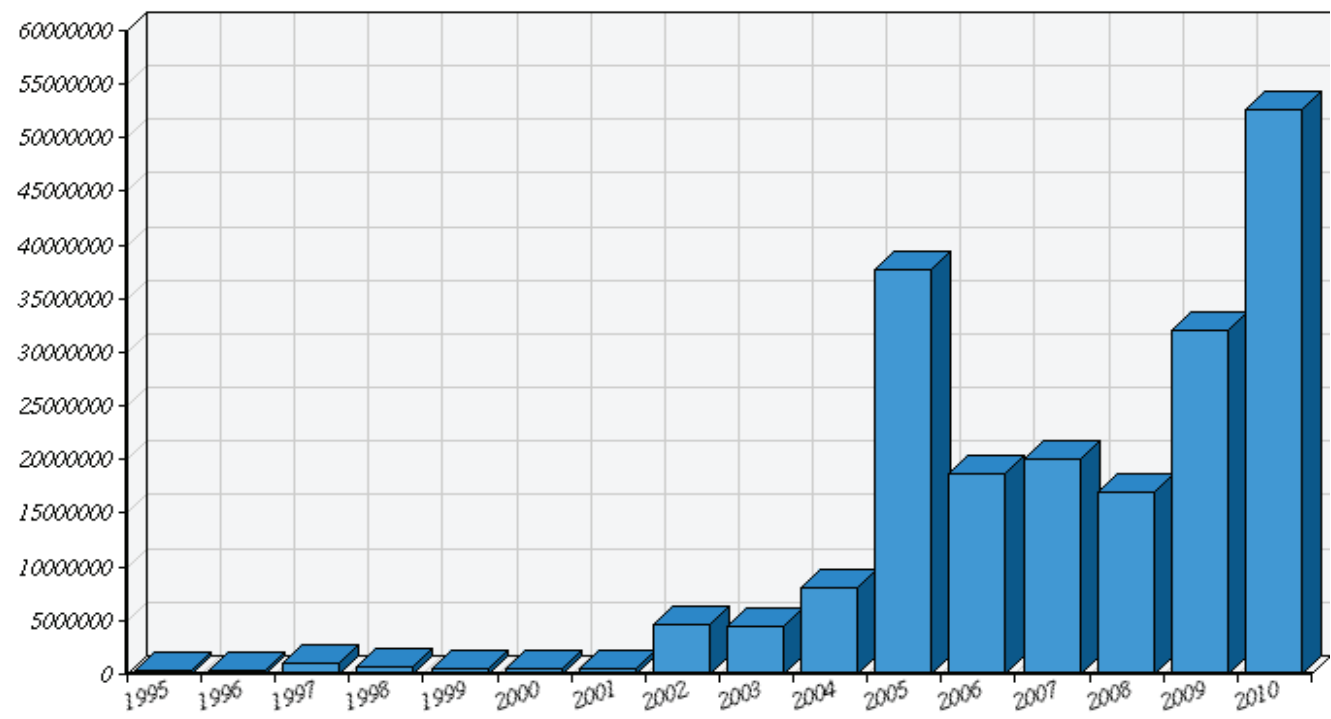

Source: Produced by the authors from two sources: Puente, 2010: 294 and Farani , 2010: slide 9. 
According to the ABC, from 2004, the Brazilian technical cooperation for development sought to strengthen Brazil's relations with developing countries, supporting projects that were national development priorities of recipient countries and those that had the involvement of local institutions, thus producing a greater impact and a multiplying effect on those countries (ABC, 2010, n.d.).

According to a report presented by the Ministry of Foreign Affairs (MRE), the number of projects implemented by the ABC greatly increased during the Lula government. In 2003, the ABC had started 34 projects. In 2009, 96 projects were started (MRE, 2011, n.d.). Regarding the recipient countries, in $2009,50 \%$ of the projects were implemented in African countries, 39\% in countries of South and Central America and the Caribbean, and $11 \%$ in Asia and the Middle East. The main areas covered by these projects and activities were: agriculture (21.86\%), health (16.28\%), education $(12.12 \%)$, environment $(7.43 \%)$, and public safety (6.28\%). The projects in the area of social development made up 5.31\% of the initiatives (MRE, 2011, n.d.). ${ }^{23}$

\section{Humanitarian Assistance in Lula's Government}

The Brazilian Ministry of Foreign Affairs defines international humanitarian assistance as:

Any action that contributes, in an immediate and effective way, to prevent, protect from, prepare for, reduce or alleviate suffering and to provide assistance to other countries or regions that are - temporarily or otherwise - in situations of emergency, public calamity, imminent or serious threat to life, to health, to the protection of human rights or the humanitarian rights of its population (MRE, 2010).

Brazil's performance as a provider of international humanitarian assistance is based on two complementary UN General Assembly resolutions: 46/182 and 58/114. The first (46/182), from 1991, sets out the principles that must be observed in providing this sort of assistance: humanity, neutrality and impartiality. Since the sovereignty of states must never be violated, humanitarian assistance should be provided only with the consent of the affected country. The second resolution (58/114), from 2003, emphasises the need for cooperation on humanitarian assistance. It encourages governments, international organizations, and NGOs to cooperate with the Emergency Relief Coordination, of the UN Secretary-General, and to follow the resolutions of the UN Economic and Social Council (ECOSOC). 
In Lula's government, Brazilian humanitarian assistance went through a growing process of institutionalization and there was great concern for its operation. This took place after the creation of the General Coordination for International Action Against Hunger (CGFOME), linked to the Office of the General Secretary of the Ministry of Foreign Affairs by Decree No. 4759, of June 21, 2003. According to the General Coordinator of CGFOME, Minister Milton Rondó Filho, CGFOME was created to be the "external interface" of the Zero Hunger Programme ${ }^{24}$, providing humanitarian assistance and emergency actions on food security. ${ }^{25}$

Moreover, the Inter-Ministerial Working Group on Humanitarian Assistance (GTIAHI) was created by a decree published on June 21, 2006 in order to coordinate the efforts of Brazilian international humanitarian aid and to formulate a bill that would permanently authorize the donation of food, medicine and other items from Brazilian public stocks to international humanitarian actions. Thus, on April 17, 2007 bill $n^{0} 737^{26}$ was presented for this purpose, as these donations were being sent by means of Provisory Measures ${ }^{27}$, which authorized the shipments. In addition, in 2009, the first humanitarian warehouse in Brazil, at the International Airport of Rio de Janeiro, was set up with the aim of expediting humanitarian assistance.

Humanitarian assistance, as well as other actions comprising the "humanistic" and "solidarity-based" trend of Brazilian foreign policy, divides opinion within the country. The Observatory of the Metropolises, in partnership with other national and international organizations, conducted a survey in major metropolitan areas of Brazil to understand the exercise of citizenship in these regions. The survey was also conducted in six other countries: Canada, the United States, France, Sweden, Spain and Portugal. In it, respondents were asked about the importance of "helping people around the world who live in precarious situations". The indicator varies from zero to seven (seven = Very important; zero $=$ Not important at all) and Brazil came first in the ranking, with an average of 6.23, followed by Spain, Portugal, Canada and Sweden (Azevedo; Santos; Ribeiro, 2009: 353). Since only $43 \%$ of the Brazilian population lives in metropolitan areas, the results cannot be extrapolated to the whole population. Nevertheless, they suggest strong internal support for the "humanistic" and "solidarity-based" foreign policy actions. On the other hand, according to Milton Rondó Filho, coordinator of CGFOME, the opposition parties have been against the approval of Bill 737/2007. This controversy is illustrated by the declaration of separate voting by Deputy Fernando Coruja (PPS - Socialist Popular Party):

Although the intention is commendable, this House cannot give up its prerogative to review the allocation and type of humanitarian aid to be granted case by case, otherwise we will succumb to a logic of executive power that often goes beyond common sense and can border on the absurd, penalizing the Brazilian people" (BRASIL, 2008a). 
The initiative was also subject to pressure from other leftist parties. Heloísa Helena, then Senator for the Socialism and Freedom Party (PSOL), made a speech in 2004 criticizing giving humanitarian assistance to other countries instead of providing aid to needy states in Brazil:

I appeal once again to humanitarian aid for the Brazilian states that suffer emergencies and floods. Of course, I have much sympathy for the people of Africa, the Arab World and Latin America. There is no problem with that. I just want humanitarian aid to also be provided to Brazil. A government that throws in the mud of speculation $70 \%$ of the public budget, that chooses to fill bankers' bellies while emptying the plates, jobs and dignity of the Brazilian people has no moral authority to demand humanitarian aid, saying that someone in this House was against it. No one is against it. Lies! [...]. Solidarity with others, yes, but also solidarity with the Brazilian people!" (Senado Federal, 2004).

The humanitarian assistance provided by Brazil during the Lula administration consisted of donations in kind (food, medicine and general items), sending in Brazilian professionals to help ${ }^{28}$, cash donations ${ }^{29}$ and participation in multilateral dialogues on humanitarian assistance. ${ }^{30}$ The funds for international humanitarian assistance are authorized by the Annual Budget Law (LOA), under the responsibility of the Ministry of Foreign Affairs (MRE). In 2010, the international humanitarian assistance budget was R $\$ 50$ million. According to a study by the Institute for Applied Economic Research (IPEA) and the ABC, Latin American and Caribbean countries received 76.27\% of Brazilian humanitarian aid between 2005 and 2009. The Asian continent received 16.44\% and Africa received 7.26\% of these resources. Oceania received $0.02 \%$ of the Brazilian aid during that period (IPEA and $\mathrm{ABC}, 2010)$.

\section{Financial Cooperation}

In addition to the initiatives briefly presented in the previous sections, Brazil made other efforts that enhanced the "humanistic" and "solidarity-based" character of its foreign policy strategy. Within the scope of financial cooperation, the Brazilian government deducted a significant amount from the debt that poorer countries had with Brazil, especially African countries. Among the beneficiaries were Mozambique, Nigeria, Gabon, Cape Verde and Bolivia, among others. As the National Monitoring Report of the Millennium Goals points out, "the discounts granted to developing countries in debt with Brazil amounted to US $\$ 1.25$ billion, of which more than US $\$ 1$ billion pertained to heavily indebted poor countries" (IPEA, 2010: 159). 
This policy has also generated controversy. There are many questions regarding whether or not Brazil should have cancelled some of these countries' debts. In September 2004, Deputy Antonio Carlos Mendes Thame, from the Brazilian Social Democracy Party, presented Bill No. 4128, which required the Executive to obtain specific and express permission from Congress to relieve debt. As justification, the deputy argued:

Despite the merits of the announced motivation for such international acts (solidarity), we agree with the chairman of the Federal Bar Association of Brazil, who has publicly declared that he did not find any device in the Federal Constitution that gives powers to the Brazilian President to unilaterally forgive debts or make donations with public money to other countries (Thame, 2004).

The bill was in process until 2010, when it was declared unconstitutional by means of a report by the Committee on Constitution, Justice and Citizenship (CCJC) of the National Congress (Congresso Nacional, 2010).

In addition to debt relief, Lula proposed the creation of the "Action against Hunger and Poverty" programme in 2004, an attempt to diversify the international agenda. This action was supported by Heads of Government such as Jacques Chirac (France), Ricardo Lagos (Chile) and José Luís Zapatero (Spain), as well as UN Secretary-General Kofi Annan. The unprecedented nature of this initiative was the fact that it proposed to create and implement innovative financing mechanisms able to finance actions to eradicate hunger and poverty. In 2006, the proposal evolved into a pilot project and UNITAID, a central medicine purchasing facility at the headquarters of the World Health Organization, funded by a solidarity tax on airline tickets, was created.

In the next section we will present the intragovernmental coordination efforts put into practice for implementing technical cooperation and international humanitarian assistance, highlighting the most relevant actors involved at the domestic level.

\section{Intragovernmental Coordination for the implementation of South-South Technical Cooperation and International Humanitarian Assistance}

To understand the process of implementing foreign policy in Brazil it is necessary to contextualize the special dynamics of this policy. The Itamaraty has historically centralized this process. Its high level of professionalization, bureaucratic autonomy, and insulation at times enabled the MRE to reach an almost monopolistic control over how foreign policy is conducted (Cason and Power, 2009; Cheibub, 1985; Faria, 2012; Pinheiro, 2009). According to Faria (2008), other factors have also contributed to this centralization: the 
dominance of the Executive in Brazilian foreign policy; the fact that Brazilian legislators delegated responsibility for its formulation to the Executive; ${ }^{31}$ the country's international isolation, which was also an outcome of adopting the development model through import substitution; and the traditional "non-conflictive" practice of Brazilian diplomacy (Faria, 2008: 81).

However, the Itamaraty's insulation has become less pronounced since the country's redemocratization in 1985 and after the economic liberalization that took place in the beginning of the 1990s, which led to the appearance of new stakeholders who tend to achieve greater influence on foreign policy decisions, in a context of the emergence of new internal distributional conflicts (LIMA, 2000). This trend highlights the increasing politicization of foreign policy in Brazil, reducing the monopoly of foreign policy production by the Ministry of Foreign Affairs (Faria, 2012), which also reflects the expansion and diversification of the country's international agenda. In this sense, new governmental actors have also come into play, and the participation of other ministries besides the MRE has become recurrent. Silva et al. (2010) have pointed out that this process of "public fragmentation of diplomacy" provides an increase in the bureaucratic spaces of foreign policy formulation and a greater dialogue with society.

The study of the current institutional arrangement of Brazilian foreign policy undertaken by the aforementioned authors demonstrated that today's competence regarding the production of foreign policy in Brazil is shared by the entire structure of the federal executive branch. Almost all ministries have a structure for international affairs. Moreover, this "horizontal decentralization" can be observed both during the decision/formulation and the implementation phases (Silva et al., 2010). In the next subsection, the activities undertaken by the various ministries and governmental agencies mobilized to put the solidarity-based foreign policy into practice will be analysed in the context of technical cooperation and international humanitarian assistance. Financial cooperation with less developed countries involves a much smaller number of governmental agencies, demanding an implementation structure that is not so complex, this being the reason for which it will not be further discussed in this paper.

\section{Intragovernmental Coordination for the implementation of South-South Technical Cooperation}

According to Puente (2010), one of the hallmarks of Brazilian horizontal cooperation is the fact that a multitude of actors participate in the domestic conception and implementation of cooperation. In addition to its role in coordinating Brazilian international cooperation, the ABC also acts in the "recruitment and mobilization" of cooperating 
institutions, which, in most cases, act as executors and are fundamental to implementing many of the actions.

It is estimated that more than 120 national institutions are involved in delivering technical cooperation. These include ministries, departments, foundations, universities, private companies, NGOs, and various sub-national entities (Ayllón and Leite, 2010).

The network of agencies and organizations that deliver Brazil's technical cooperation is coordinated by the ABC. According to Decree $n^{0} 7304$ of September 22, 2010, the Agency has the primary function of coordinating cooperation activities, but it is also responsible for negotiating, monitoring, evaluating, planning etc. However, it seldom acts as a direct executor of cooperation projects (BRASIL, 2010b).

Figure 2 shows the institutional design of the Brazilian technical cooperation, as well as the intragovernmental network mobilized for its implementation. It depicts the main ministries and executing agencies of technical cooperation. Among them, the Brazilian Agricultural Research Corporation (EMBRAPA) stands out. Its expertise in the area of tropical agriculture enables the transfer of its technology to developing countries. According to Ayllón and Leite (2010), the company has technical cooperation agreements with more than 50 countries and runs $65 \%$ of the $\mathrm{ABC}$ projects in the area of tropical agriculture. An EMBRAPA regional office was recently opened in Ghana.

In the area of public health, the Ministry of Health (MS) plays a central role. In 2010, through Ordinance $\mathrm{n}^{\mathrm{o}}$ 2356, the MS created the Working Group on International Cooperation on Health to strengthen and expand the connection and coordination of the Ministry's partnerships with others actors. Projects to support the structuring of national programmes to prevent and cure diseases like HIV/Aids are worthy of note, as is the implementation of human milk banks and support for the production of medicines in collaboration with the Oswaldo Cruz Foundation (FIOCRUZ), which recently established a branch in Mozambique (Farani, 2009). ${ }^{32}$

Another form of Brazilian technical cooperation is the transfer of methodology of some of the social policies considered most successful in the Lula government. The Ministry of Social Development and Fight against Hunger (MDS) is significantly involved in developing technical cooperation with developing countries, as some of these social policies fall under its responsibility. ${ }^{33}$ Until 2010, the MDS had signed 62 international cooperation agreements, in the form of memorandums, cooperation projects, letters of intent and other related documents. Most of them are part of the South-South cooperation delivered by the country (MDS, 2010). 
Figure 2: Institutional Setup of Brazilian Technical Cooperation

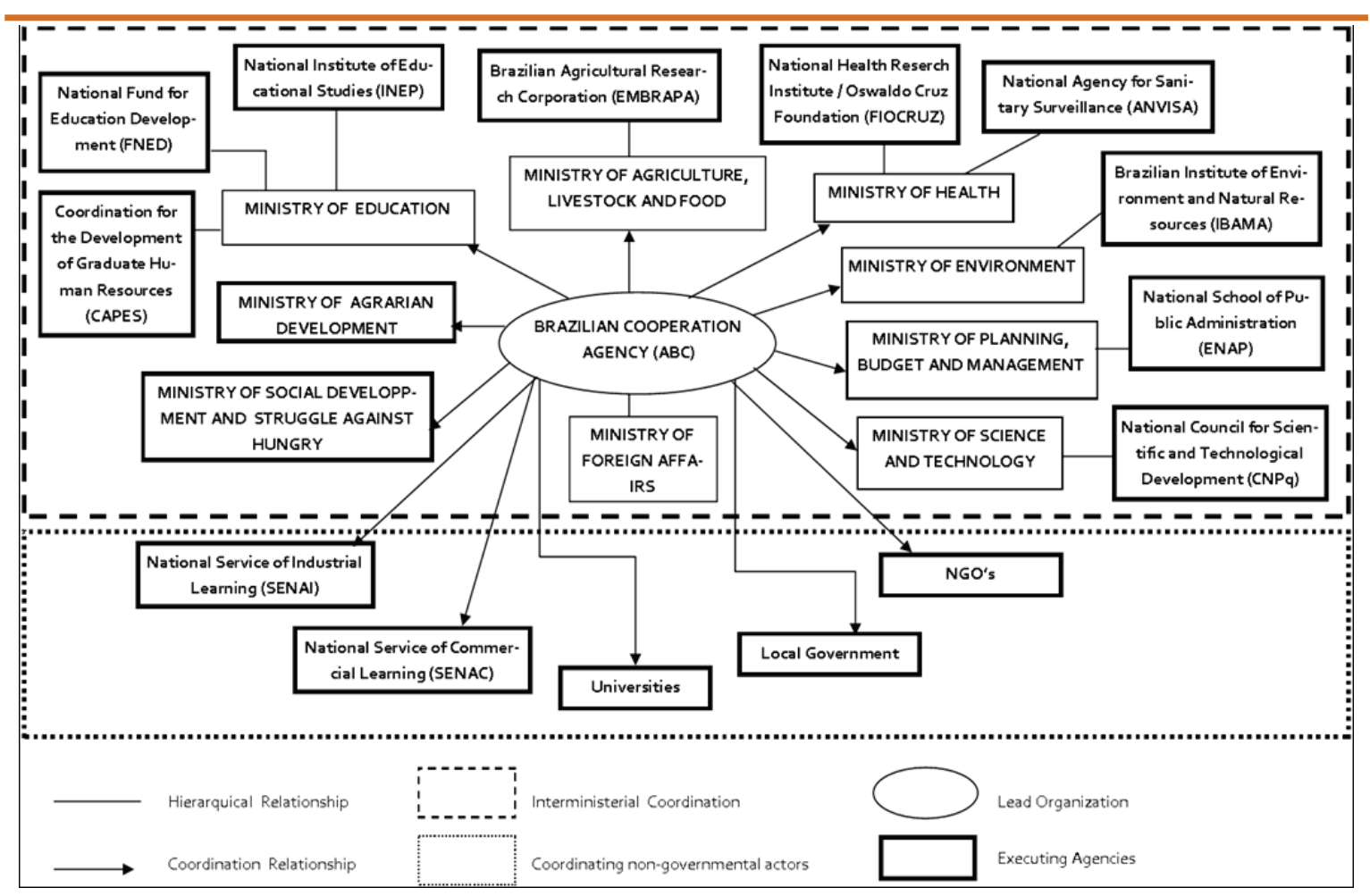

Source: Author's elaboration

In the area of professional qualification, there is the involvement of institutions such as the National Service for Commercial Learning (SENAC) and the National Service for Industrial Learning (SENAI). The latter has projects for restructuring education systems and for creating professional training centres in Portuguese-speaking countries (Angola, Cape Verde, Guinea-Bissau, East Timor) and Latin America (Paraguay and Colombia) (SENAI, n.d.).

In the area of education, Brazil transfers the methodology from the National School Food Programme (PNAE), which operates under the control of the National Fund for Educational Development (FNDE). In 2010, thirteen countries kept cooperative agreements with the Fund (FNDE, 2010). Furthermore, in this same area, there is the project the NGO Solidarity in Literacy (Alfasol) has with the ABC, providing training for teachers and technical staff in basic literacy and education for young people and adults in Cape Verde (Alfabetização Solidária, 2009).

\section{Intragovernmental Coordination for the Implementation of Brazilian International Humanitarian Assistance}

The main institutional mechanism that operates international humanitarian assistance provided by Brazil is the Interministerial Working Group on Humanitarian 
Assistance (GTIAHI). The Brazilian system of international humanitarian assistance includes a set of activities developed by a series of ministries and federal government agencies. ${ }^{34}$ Figure 3 shows the actors involved in the provision of humanitarian assistance, as well as their mode of participation.

Figure 3: Institutional Setup of Brazilian International Humanitarian Aid

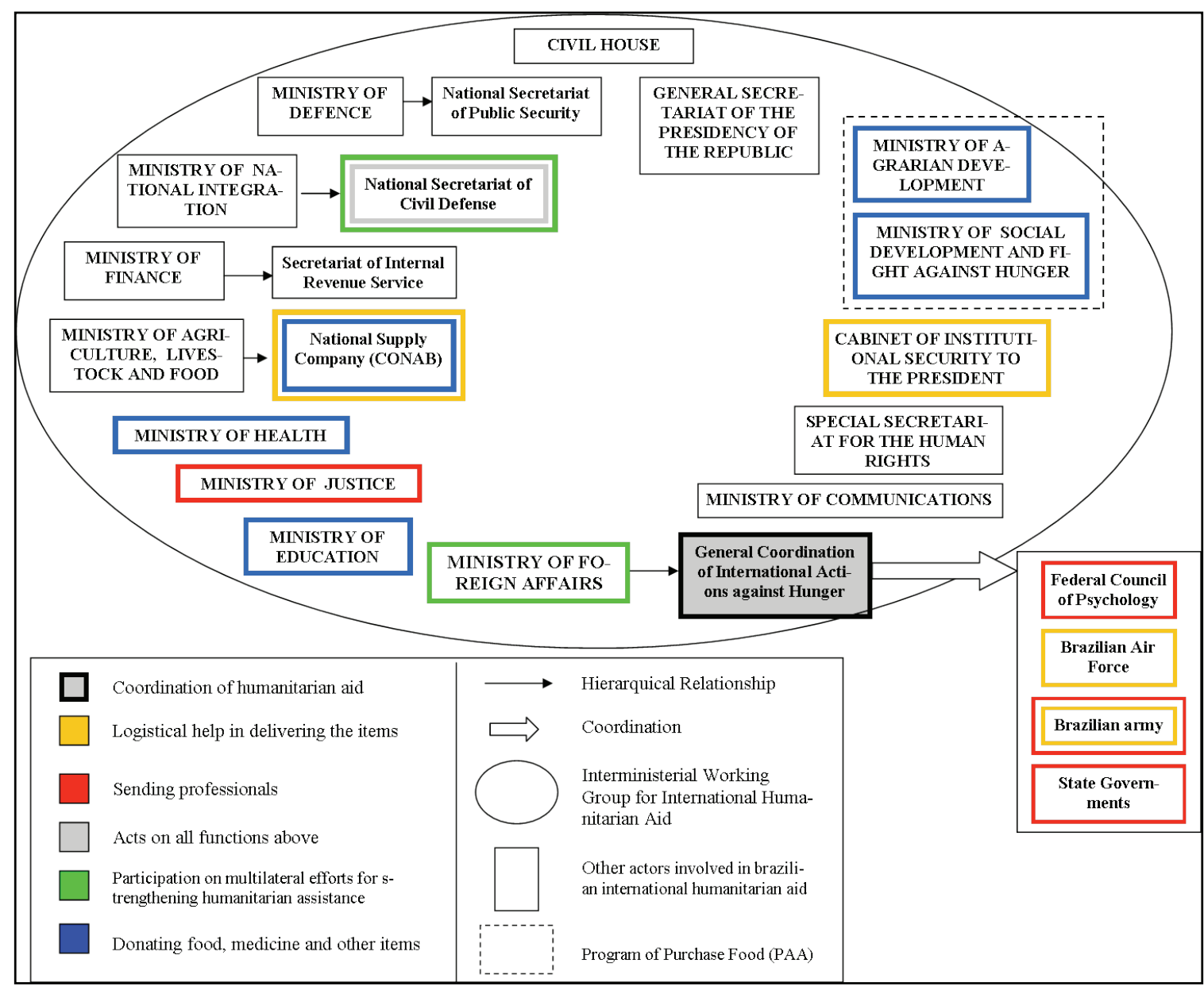

Source: author's elaboration

The National Supply Company (CONAB) - linked to the Ministry of Agriculture, Livestock and Supply - has an important role in international humanitarian assistance. Its general function is to manage the outflow of the national harvest, to build public stocks and to sell them according to market movements (CONAB, 2010). The role of the CONAB in international humanitarian aid is to act in the purchase of food, storage and distribution logistics. Between 2004 and March 2007, it allocated nearly 220 tonnes of food for humanitarian assistance (CONAB, 2007: 5).

Another important agency in the provision of international humanitarian assistance is the National Civil Defence Agency, which is linked to the Ministry of National Integration. According to Decree $\mathrm{n}^{\mathrm{o}} 7257$ of 2010, the Agency is responsible for the articulation, 
coordination and technical supervision of the National System of Civil Defence (SINDEC), and seeks to build preventative rescue, and recuperative care; to prevent disasters; and to minimize their impacts on the population. It is responsible for the humanitarian assistance provided by Brazil (BRASIL, 2010a) and operates internationally, donating items to countries affected by conflict or natural disasters; sending in trained professionals; and representing Brazil in multilateral dialogue forums dedicated to humanitarian assistance, such as the Global Platform for Disaster Reduction in 2009.

In addition, we should mention the Cabinet of Institutional Security (GSI), linked to the Presidency. Its function, among others, is to prevent the occurrence of crises and coordinate their management (GSI, n.d.). In international humanitarian assistance, its role is to liaise with other agencies to provide the logistics of assistance. In January 2010, the Office gave support to victims of the earthquakes in Chile and Haiti (Aguilar, 2012).

The role of the Ministry of Agrarian Development (MDA) and the Ministry of Social Development and Fight against Hunger (MDS) in international humanitarian assistance manifests mainly through the Food Acquisition Programme (PAA). ${ }^{35}$ They carry out the donation of food coming from government stocks and bought from family farmers.

This brief mapping of programmes, projects, activities and priorities that make the "humanistic" and "solidarity-based" foreign policy of the Lula administration concrete allows us to understand its domestic operation. The creation of the General Coordination of International Actions Against Hunger (CGFOME), linked to the Itamaraty, the significant increase in both the number of projects and budget of the Brazilian Cooperation Agency $(\mathrm{ABC})$ and the greater institutionalization of international humanitarian assistance, through the creation of the Interministerial Working Group for International Humanitarian Assistance (GTIAHI), are some of the ways in which the rhetoric of international solidarity has been translated into practice.

These initiatives rely on the participation of several ministries and other public agencies, which strengthens the thesis of "horizontal decentralization" in the production of foreign policy. The Itamaraty has been losing exclusive control over external issues to other parts of the state bureaucracy. Today, almost all the ministries have their own institutional structures for handling their international interests. In addition, the expansion and greater complexity of the Brazilian international agenda during the Lula government reinforced the need to involve other ministries, not only the MRE, which does not have sufficient organizational capacity, technical expertise or the authority to implement at the national level many of the decisions taken at the international level. Coordination problems, however, are still legion (Ayllón and Leite, 2010). The proper functioning of coordination mechanisms and the creation and institutionalization of new mechanisms are crucial for the maintenance and longevity of those policies at the top of the Brazilian government's international agenda. 
Additionally, improving the accountability of these policies is essential, as it helps to ensure transparency and legitimacy. The importance of accountability becomes even greater as these actions are not free from controversy. As we have seen, assistance provided to other countries from the South, in the form of technical or humanitarian assistance, can and has in fact been regarded as incompatible with the social obstacles Brazil still faces.

\section{Concluding Remarks}

In order to discuss the theory and practice of the humanistic trend in Brazilian foreign policy under Lula (2003-2010), we have used different sorts of arguments (related to three levels of analysis - the individual, the state and the international, both regionally and globally) and stressed the relevance of various actors (politicians, bureaucrats, political parties and domestic and international institutions). In order to provide more than the panoramic view that we have given here, it would be necessary to touch not only on International Relations Theory, but also on Political Science, History, Public Administration, Political Psychology and Sociology of Organizations. After all, foreign policy analysis is a multidisciplinary field almost by definition. ${ }^{36}$

So, what has been the actual impact of this innovation in Brazilian foreign policy, also considering that its scope was not restricted to the national level? One could say that new institutions and social programmes were created and that old ones were strengthened; that it helped to give Brazil a special place on the world stage, an outstanding one, according to many; that it mobilized actors and institutions at home and abroad; that it helped change the international agenda; and that it promoted social improvement. Its sole impact on poverty and hunger alleviation is certainly very difficult to measure. It is therefore not absurd to say that its most visible impact, at least from the viewpoint of 2013, has been essentially political.

As Brazilians tend to interpret the merits of the country's foreign policy in terms of economic gains and benefits, as suggested by Lima (2005b), one could foresee that, as a policy innovation, such a humanistic trend would not endure the sequence of the electoral cycle. But Lula himself chose his successor, Dilma Rousseff, who was virtually unknown to most Brazilians a few months before the 2010 presidential election. During the contest in which PT's/Lula's candidate was victorious, Lula repeatedly recalled the collective pride that his two terms in office supposedly managed to promote, which can be seen as a direct product of his foreign and social policies. The priority to the South-South axis is an entrenched tradition of the Workers' Party. Rousseff also kept Marco Aurélio Garcia as her advisor for international affairs, the same member of the PT cadre who held the post during Lula's eight years in office. 
In a recent seminar promoted by Perseu Abramo Foundation, an official PT think tank, Garcia said that Latin American integration "needs to be different", that "we need a solidarity-based integration". "We Brazilians do not want to be Latin American Germany." ${ }^{37}$ And there are several other indications of policy continuity.

Dilma Rousseff's government seems to preserve the foreign policy innovation it inherited from the previous president, a policy orientation that does not reflect international altruism, but an international posture of "enlightened self-interest", according to Lima's (2005b) sympathetic suggestion. However, if such a standing results in Brazil becoming a "post-imperial power", as Brazilian leftist media has suggested, it is a possibility that will probably make entrenched realists smile and change the subject. An "offensive realist" might not react so politely... Be that as it may, Brazil has already been labelled "the soft power great power" (Dauvergne and Farias, 2012: 913).

Revised by Priscila Moura

Submitted in August 2012

Accepted in June 2013

\section{References}

AGÊNCIA BRASILEIRA DE COOPERAÇÃO. CGPD - Coordenação Geral de Cooperação Técnica entrePaísesemDesenvolvimento. <http://www.abc.gov.br/abc/coordenacoesCGPDIntroducao. asp> (accessed November 10, 2010).

AGÊNCIA BRASILEIRA DE COOPERAÇÃO. (n.d.), Projetos de Cooperação Sul-Sul. < http:// www.abc.gov.br/projetos/cooperacaoPrestada.asp> (accessed September 12, 2010).

AGUILAR, Sérgio. (2012), Emerging powers, humanitarian assistance and foreign policy: the case of Brazil during earthquake crisis in Haiti. International Journal of Humanities and Social Science, vol.2, no 16 , pp. 93-101.

ALEXANDRE, Cristina Vieira Machado. (2006), O Congresso Brasileiro e a Política Externa: 19852005. (Master Dissertation, International Relations Institute, Pontifical Catholic University of Rio de Janeiro,PUC-Rio.

ALFABETIZAÇÃO SOLIDÁRIA. (2009), Alfabetização Solidária, 13 anos: percursos $e$ parcerias. <http://www.alfabetizacao.org.br/aapas_site/adm/file/publicacao/201001281628_ Alfasol_13anos.pdf> (accessed May 10, 2010). 
ALMEIDA, Paulo Roberto de. (2004), Uma política externa engajada: a diplomacia do governo Lula. Revista Brasileira de Política Internacional, vol.47, nº 1, pp.162-184.

ALMEIDA, Paulo Roberto de. (2005), Uma nova arquitetura diplomática? Interpretações divergentes sobre a política externa do governo Lula (2003-2006). Revista Brasileira de Política Internacional, vol. 49, n ${ }^{\circ}$ 1, pp. 95-116.

ALMEIDA, Helga do Nascimento de. (2013), O Congresso e a política externa: um estudo sobre a Câmara dos Deputados brasileira no governo Lula. (Master Dissertation, Political Science, Federal University of Minas Gerais, UFMG.

AMORIM, Celso. (2010), Sempre digo que Pelé só teve um; igual a Lula não vai ter. Folha de São Paulo -online version. 15/11/2010. Entrevista concedida a Eliane Cantanhêde. <http://www1. folha.uol.com.br/poder/830614-celso-amorim-sempre-digo-que-pele-so-teve-um-igual-a-lulanao-vai-ter.shtml $>$ (accessed November 19, 2010).

ANDERSON, Perry. (2011), Lula's Brazil. London Review of Books, vol.33, nº 7, pp. 3-12.

AYLLÓN, Bruno and LEITE, Iara Costa. (2010), La cooperación Sur-Sur de Brasil: ¿̇nstrumento de política exterior y/o manifestación de solidaridad internacional? Mural Internacional, ano $1, \mathrm{n}^{\mathrm{o}} 1$.

AZEVEDO, Sérgio de; SANTOS Jr., Orlando Alves; RIBEIRO, Luiz César de Queiroz. (2009), Metrópoles, cultura política e cidadania no Brasil. Cadernos Metrópole, vol.11, n 22, pp. 347366.

BRASIL. (2003), Decreto n 4.759 de 21 de junho de 2003. Aprova a Estrutura Regimental e o Quadro Demonstrativo dos Cargos em Comissão e das Funções Gratificadas do Ministério das Relações Exteriores, e dá outras providências. < http://www.planalto.gov.br/ccivil_03/ decreto/2003/D4759.htm>

BRASIL. (2010a), Decreto ${ }^{0} 7.257$ de 04 de agosto de 2010. Regulamenta a Medida Provisória ${ }^{\circ}$ 494 de 2 de julho de 2010, para dispor sobre o Sistema Nacional de Defesa Civil - SINDEC, sobre o reconhecimento de situação de emergência e estado de calamidade pública, sobre as transferências de recursos para ações de socorro, assistência às vítimas, restabelecimento de serviços essenciais e reconstrução nas áreas atingidas por desastre, e dá outras providências. < http://www.planalto.gov.br/ccivil_03/_Ato2007-2010/2010/Decreto/D7257.htm> .

BRASIL. (2010b), Decreto $\mathrm{n}^{0} 7.304$ de 22 de setembro de 2010. Aprova a Estrutura Regimental e o Quadro Demonstrativo dos Cargos em Comissão e das Funções Gratificadas do Ministério das Relações Exteriores, e dá outras providências. <http://www.planalto.gov.br/ccivil_03/_ Ato2007-2010/2010/Decreto/D7304.htm\#art6>.

BURGES, Sean W. (2005), Auto-estima in Brazil. The logic of Lula's south-south foreign policy. International Journal, Autumn, pp.1133-1151.

BURGES, Sean W. (2007), Building a Global Southern Coalition: the competing approaches of Brazil’s Lula and Venezuela's Chávez. Third World Quarterly, vol.28, nº7, pp.1343-1358.

CASON, Jeffrey W. and POWER, Timothy J. (2009), Presidentialization, Pluralization, and the Rollback of Itamaraty: Explaining Change in Brazilian Foreign Policy Making in the CardosoLula Era. International Political Science Review, vol. 30, n 2, pp.117-140. 
CHEIBUB, Zairo B. (1985), Diplomacia e Construção Institucional: o Itamaraty em uma perspectiva histórica. Dados, vol. 28, nº1, pp. 113-131.

COMPANHIA NACIONAL DE ABASTECIMENTO. A CONAB e a Assistência Humanitária Internacional. Mar. 2007. <http://www.assistenciahumanitaria.mre.gov.br/documentos/ CONAB.pdf $>$ (accessed February 19, 2010).

COMPANHIA NACIONAL DE ABASTECIMENTO (2010), Quem Somos. < http://www.conab. gov.br/conteudos.php?a=11\&t=>

DANESE, Sérgio França. (1999), Diplomacia Presidencial: História e Crítica. Rio de Janeiro: Topbooks.

DAUVERGNE, Peter and FARIAS, Déborah B. (2012), The rise of Brazil as a global development power. Third World Quarterly, vol. 33, n5, pp. 903-917.

DINIZ, Simone and RIBEIRO, Cláudio Oliveira. (2008), The role of the Brazilian Congress in foreign policy: an empirical contribution to the debate. Brazilian Political Science Review, vol.2, $\mathrm{n}^{\mathrm{0}} 2, \mathrm{pp} .10-38$.

FARANI, Marco (2010). Agência Brasileira de Cooperação. In: Seminário Brasil e China na África: Desafios da Cooperação para o Desenvolvimento. Brasília, Jun. 9, 2010. 27 slides: PowerPoint. <http://www.cebri.com.br/midia/documentos/minmarcofaranichinanaafrica972003.pdf> (accessed November 10, 2010).

FARANI, Marco. (2009), Cooperação Sul-Sul. Boletim da Atuação Internacional Brasileira em Saúde, Ministério da Saúde, $\mathrm{n}^{\circ} 1$, outubro, pp. 6-6.

FARIA, Carlos Aurélio Pimenta de. (2008), Opinião pública e política externa: insulamento, politização e reforma na produção da política exterior do Brasil. Revista Brasileira de Política Internacional, vol.51, $\mathrm{n}^{\circ} 2$, pp. 80-97.

FARIA, Carlos Aurélio Pimenta de. (2012), O Itamaraty e a política externa brasileira: do insulamento à busca de coordenação dos atores governamentais e de cooperação com os agentes societários. Contexto Internacional, vol. $34, \mathrm{n}^{\mathrm{o}} 1$, pp.311-355.

FUNDO NACIONAL DE DESENVOLVIMENTO DA EDUCAÇÃO. (2010), Nações Unidas conhece alimentação escolar brasileira. <http://www.fnde.gov.br/fnde/sala-de-imprensa/ noticias/item/1926-nações-unidas-conhece-alimentação-escolar-brasileira>. (Accessed June 5, 2011).

GABINETE DE SEGURANÇA INSTITUCIONAL DA PRESIDÊNCIA DA REPÚBLICA. (n.d.), Sobre o Gabinete de Segurança Institucional. <http://www.gsi.gov.br/sobre>. (Accessed November16, 2010).

HUDSON, Valerie M. (2007), Foreign policy analysis: classic and contemporary theory. Maryland, Rowman \& Littlefield Publishers.

HURRELL, Andrew (2008), Lula's Brazil: a Rising Power, but Going Where? Current History, February, pp. 51-57.

INSTITUTO DE PESQUISA ECONÔMICA APLICADA. (2010), Cooperação brasileira para o desenvolvimento internacional: 2005-2009. <http://www.ipea.gov.br/portal/images/stories/ PDFs/Book_Cooperao_Brasileira.pdf >. (Accessed June 5, 2011). 
LIMA, Maria Regina Soares (2000), Instituições democráticas e política exterior. Contexto Internacional, vol. 22, $\mathrm{n}^{\mathrm{0}} 2$, pp. 265-303.

LIMA, Maria Regina Soares. (2005a), Aspiração internacional e política externa. Revista Brasileira de Comércio Exterior, vol.19, no 82, 2005, pp. 4-19.

LIMA, Maria Regina Soares. (2005b), Autonomia, não-indiferença e pragmatismo: vetores conceituais da política exterior. Revista Brasileira de Comércio Exterior, no 83, pp. 16-20.

LIMA, Maria Regina Soares de and HIRST, Mônica. (2006), Brazil as an intermediate state and regional power: action, choice and responsibilities. International Affairs, vol. 82, $\mathrm{n}^{0}$ 1, pp. 21-40.

LIMA, Maria Regina Soares de and SANTOS, Fabiano. (2001), O Congresso e a política de comércio exterior. Lua Nova, n ${ }^{\circ}$ 2, pp. 121-149.

MINISTÉRIO DAS RELAÇÕES EXTERIORES (2010). Assistência humanitária. <http:// www.itamaraty.gov.br/temas/acao-contra-a-fome-e-assistenciahumanitaria/assistenciahumanitaria/view> (accessed November10, 2010).

MINISTÉRIO DAS RELAÇÕES EXTERIORES. (n.d.), Balanço de Política Externa 2003/2010. 7.1.1 Anexo - Cooperação Internacional. Cooperação bilateral prestada. <http://www. itamaraty.gov.br/temas/balanco-de-politica-externa-2003-2010/7.1.1-anexo-cooperacaointernacional.-cooperacao-bilateral-prestada/view >. (accessed May 28, 2011).

MINISTÉRIO DO DESENVOLVIMENTO AGRÁRIO. (n.d.), Secretaria da Agricultura Familiar. Programas - Programa de Aquisição de Alimentos (PAA). < http://portal.mda.gov.br/portal/ saf/programas/paa $>$. (Accessed November10, 2010)

MINISTÉRIO DO DESENVOLVIMENTO SOCIAL E COMBATE À FOME. (n.d.), Fome Zero O que é. < http://www.fomezero.gov.br/o-que-e>. (Accessed June 5, 2011).

MINISTÉRIO DO DESENVOLVIMENTO SOCIAL E COMBATE Á FOME (2010). Sobre o Ministério. Relações Internacionais. <http://www.mds.gov.br/sobreoministerio/ relacoesinternacionais $>$. (Accessed December 2, 2010).

OBJETIVOS DE DESENVOLVIMENTO DO MILÊNIO. Relatório Nacional de Acompanhamento. Brasília, Ipea, 2010. <http://agencia.ipea.gov.br/images/stories/PDFs/100408_relatorioodm. pdf $>$ (Accessed June 14, 2010).

PANIZZA, Francisco. (2006), La marea rosa. Análise de Conjuntura OPSA, nº8.

PINHEIRO, Letícia. (2009), Autores y Actores de la Política Exterior Brasileña. Foreign Affairs Latinoamérica, vol. 9, $\mathrm{n}^{\circ}$ 2, pp.14-24.

PINHEIRO, Letícia and VEDOVELI, Paula. (2012), Caminhos Cruzados: Diplomatas e Acadêmicos na Construção do Campo de Estudos de Política Externa Brasileira. Revista Política Hoje, vol. $21, \mathrm{n}^{\mathrm{o}} 1$, pp. 211-254.

PUENTE, Carlos Alfonso Iglesias. (2010), A cooperação técnica horizontal brasileira como instrumento de política externa: a evolução da cooperação técnica com países em desenvolvimento (CTPD) no período 1995-2005. Brasília: FUNAG.

RIBAS, Letícia Diniz and FARIA, Carlos Aurélio Pimenta de. (2011), A política externa vista da janela do avião: a diplomacia presidencial nos governos FHC e Lula, Paper presented at III 
Simpósio de Pós-Graduação em Relações Internacionais do Programa Santiago Dantas. São Paulo, November 2011. <http://www.santiagodantassp.locaweb.com.br/br/simp/artigos2011/ leticia_ribas_carlos_faria.pdf $>$.

RICUPERO, Rubens. (2010), À sombra de Charles De Gaulle: uma diplomacia carismática e intransferível - A política externa do governo Luís Inácio Lula da Silva (2003-2010). Novos Estudos, no 87 , pp.35-58.

RIPLEY, Brian. (1993), Psychology, Foreign Policy, and International Relations Theory. Political Psychology, vol. 14, nº 3, pp. 403-416.

ROUQUIÉ, Alain (2008). "Brazil, a South American state among the key players". Global insights. <http://www.ciaonet.org/book/cup/0016215/f_0016215_13994.pdf. (Accessed April 10, 2012).

SENADO FEDERAL. (2004), Pronunciamento da Senadora Heloísa Helena. 30/11/2004. Portal Atividade Legislativa. <http://www.senado.gov.br/atividade/pronunciamento/detTexto. asp? $\mathrm{t}=350593>$.

SENAI (2011). Cooperação Internacional. <http://www.senai.br/br/institucional/snai_coo. aspx $>$. (Accessed June 5, 2011).

SERVIÇO NACIONAL DE APRENDIZAGEM INDUSTRIAL. (n.d.), Cooperação Internacional. $<$ http://www.senai.br/portal/br/institucional/snai_coo.aspx $>$.

SILVA, Michelle Morais de Sá. (2010), How did we get here? The Pathways of South-South Cooperation. Poverty in Focus, International Policy Centre for Inclusive Growth, ${ }^{\mathrm{o}} 20$.

SILVA, Elaini Cristina Gonzaga da; SPÈCIE, Priscila; VITALE, Denise. (2010), Atual Arranjo Institucional da Política Externa Brasileira. Texto para Discussão, Instituto de Pesquisa Econômica Aplicada, n 1489.

SPEKTOR, Matias. (2011), O regionalismo do Brasil. Plataforma democrática, Working Paper no 16.

SOUTO MAIOR, Luiz A.P. (2004), Dois anos de presença soberana: uma reflexão sobre a política externa do governo Lula. Revista Cena Internacional, vol. 6, $\mathrm{n}^{\circ}$ 2, pp. 53-72.

SOUZA, André de Mello e. (2012), A cooperação para o desenvolvimento Sul-Sul: os casos do Brasil, da Índia e da China. Boletim de Economia e Política Internacional, no 9, pp. 89-99.

VIGEVANI, Tullo and CEPALUNI, Gabriel. (2007), A política externa de Lula da Silva: a estratégia da autonomia pela diversificação. Contexto Internacional, vol. 29, $\mathrm{n}^{\mathrm{o}}$ 2, pp. 273-335.

VILAS, Carlos M. (2005), La izquierda latinoamericana y el surgimento de regímenes nacionalpopulares. Nueva Sociedad, $\mathrm{n}^{\circ}$ 197, pp. 84-99.

\section{Notes}

1 The research that led to this paper was funded by CNPq and FAPEMIG, whom the authors wish to thank. An earlier version was presented at the World International Studies Committee WISC 2011 at Oporto, Portugal, on 17-20 August, 2011. The comments made by the anonymous reviewers of the BPSR were much appreciated. The authors want also thank Luisa Gonçalves de Medeiros and Wilson Mendonça Júnior for their research assistance. 
2 Notice that the labels and qualifications just quoted were formulated by diplomats, both retired and active (Almeida, Souto Maior and Ricupero), and by academic analysts (Vigevani and Cepaluni). Their contribution to the constitution of foreign policy as a field of study in Brazil was recently discussed by Pinheiro and Vedoveli, 2012.

3 Celso Amorim was also Minister of Foreign Affairs from June 1993 to December 1994, during Itamar Franco's presidency.

4 This was the perception one may have had from reading the editorials of leading Brazilian newspapers during the presidential race of 2002 and during the first months of Lula's presidency.

5 The pieces of discourse presented and discussed below were selected from public speeches that focused on the country's foreign policy made by both Lula and Amorim during their eight years in office (2003-2010). They can be found in the Brazilian Ministry of Foreign Affairs website, which attempts to make all official pronouncements available. They were all read and the quotations analysed in this paper were selected in order to achieve the objectives previously mentioned.

6 All speeches quoted in this section were retrieved from the Brazilian Ministry of Foreign Affairs website (http://www.itamaraty.gov.br/sala-de-imprensa). Downloaded on February 3, 2011. Authors' translations.

7 30th FAO Regional Conference for Latin America and the Caribbean. Brasília, 04/16/2008.

8 Lula, World Summit on Food Security. Rome, 16/11/2009.

9 Lula, 4th IBSA Summit. Brasília, 15/04/2010.

10 Lula, Press conference on the Global Fund to Fight Poverty. Geneva, 30/01/2004.

11 Lula, World Bank Conference on the Fight against Poverty. Shanghai, 26/05/2004.

12 FAO 60th anniversary celebration. Rome, 17/10/2005.

13 National Conference on Food Security. Brasília, 26/10/2004.

14 Amorim, High-Level Seminar on Peacekeeping Operations. Brasília, 02/05/2007.

15 In May, 2010 Lula won the World Food Day Medal from the FAO and was declared "Global Champion in the Fight Against Hunger". In the following year, he won the 2011 World Food Prize.

16 In the "Colloquy Brazil: Global Actor", held in Paris on July 13, 2005, Lula said: "Given my own life story and political experience, it [the fight against hunger and poverty] is a personal priority". The importance of political psychology to the development of Foreign Policy Analysis as a subfield of International Relations is discussed by Ripley (1993) and Hudson (2007).

17 It is important to note that Brazil's real willingness to act as a regional paymaster is still a controversial question among Brazilian foreign policy analysts, as evidence is contradictory.

18 It must be emphasised that the mapping that follows does not include all of the initiatives that make up this trend. Despite some initiatives implemented, such as the research carried out by the Institute for Applied Economic Research (IPEA) in conjunction with the Brazilian Cooperation Agency (ABC) (IPEA; ABC, 2010), the Brazilian government itself does not have a systematization of all these actions, since they are recent, numerous, growing fast, and 
involve many actors. As pointed out by Puente (2010), the cooperation activities developed by the $\mathrm{ABC}$ are poorly publicized, even within the Ministry of Foreign Affairs (MRE).

19 Source: Sistema Consular Integrado, Ministry of Foreign Affairs website, <http://dai-mre. serpro.gov.br/pesquisa_ato_bil>. Accessed April, 252012.

20 Technical cooperation is understood as a "[...] multidimensional process, which can be bilateral or multilateral in scope, regional or interregional in character. It should be held by and between governments and may count on the participation of public and private organizations. Although it is an initiative among developing countries, it should not dismiss the support of developed countries and international organizations in their implementation" (United Nations apud Puente, 2010: 78).

21 Brazilian agency responsible for international cooperation, linked to the Ministry of Foreign Affairs.

22 According to Puente, the recovery process of the ABC budget began in 2002, after the inclusion of ordinary resources for financing activities of horizontal cooperation. From 1998 to 2001, the agency's budget came from unused resources in projects of other government agencies with the UNDP. These funds were very low and from 1999 to 2001, served only to cover the administrative costs and the conditionalities of received cooperation (Puente, 2010: 145-146).

23 For a very interesting comparison between Brazilian, Chinese and Indian South-South development cooperation showing the distinctiveness of the Brazilian cooperation, see Souza, 2012.

24 The Zero Hunger Programme is a strategy driven by the federal government to ensure the right to adequate food to people with little access to it. It was the main social policy during Lula's first term in office.

25 Interview recorded at CGFOME, in Brasília, on Oct. 7, 2010.

26 This Bill of Law is still pending at the Chamber of Deputies.

27 A "provisory measure" is a legal act in Brazil through which the president can enact "laws" without previous approval by the National Congress. There are two requirements for a "provisory measure" to be issued: the urgency and the relevance of the matter to be regulated.

28 For example, doctors, psychologists, coroners, military personnel and civil defence professionals, among others.

29 These funds are used to pay for flights transporting items of humanitarian assistance, for the purchase of items in recipient countries and for voluntary contributions to UN offices and organizations involved in humanitarian assistance.

30 Specifically, in the Global Platform for Disaster Risk Reduction, within the UN International Strategy for Disaster Reduction, as a donor of the Global Facility for Disaster Reduction and Recovery (GFDRR), as organizer of the Second Regional Meeting on International Humanitarian Assistance Mechanisms and in the MERCOSUR Specialized Meeting on Social and Natural Disaster Risk Reduction, Civil Defence, Civil Protection, and Humanitarian Assistance (REHU) in 2008. 
31 This argument of a supposed legislative delegation was originally developed by Lima and Santos (2001). More recently, the literature has emphasised the contribution made by the Brazilian legislative to the production of the country's foreign policy (e.g: Alexandre, 2006; Diniz and Ribeiro, 2008; and Almeida, 2013).

32 Oswaldo Cruz Foundation is a Brazilian scientific institution for research and development in biomedicine.

33 E.g. the Zero Hunger Programme (promoting food security and nutrition), the "Bolsa Família" (a programme of income transfer, which benefits families in extreme poverty), the construction of cisterns (a receptacle for water, built to catch and store rainwater) etc.

34 The GTIAHI is coordinated by the CGFOME, linked to the MRE, and composed of the following agencies: Civil House; Ministry of Defence; Ministry of Justice, represented by the National Department of Public Security; Ministry of Finance, represented by the Internal Revenue Service; Ministry of Agriculture, Livestock and Supply, represented by the National Supply Company (CONAB); Ministry of Health, Ministry of Social Development and Fight against Hunger; Ministry of National Integration, represented by the National Civil Defence Agency; General Secretariat of the Presidency of Republic; Institutional Security Cabinet of the Presidency; Ministry of Education; Ministry of Agrarian Development; Ministry of Communications; and Special Secretariat for Human Rights.

35 "Created in 2003, the Food Acquisition Programme (PAA) is one of the actions of the Zero Hunger Programme and aims to ensure access to food in the necessary quantity and regularity for populations in situations of food and nutrition insecurity. It also aims to contribute to forming strategic stocks, allows family farmers to store their produce to be sold at fair prices and promotes social inclusion in rural areas. It is run by the Ministries of Agrarian Development (MDA) and Social Development and Fight against Hunger (MDS) with state and local governments and civil society organizations"(MDA, n.d.).

36 According to Valerie Hudson, "Explanatory variables from all levels of analysis, from the most micro to the most macro, are of interest to the analyst to the extent that they affect the decision making process. As a result, insights from many intellectual disciplines, such as Psychology, Sociology, Organizational Behaviour, Anthropology, Economics and so forth, will be useful for the foreign policy analyst in efforts to explain foreign policy decision making, making multi-/ interdisciplinarity a third hallmark of FPA [Foreign Policy Analysis]”. (2007, p.6).

37 Source: http://www.fpabramo.org.br/noticias/governos-de-esquerda-debate-analisa-integracao -da-america-do-sul-e-acoes-dos-governos. Accessed July 1, 2011. 